\title{
Early postoperative arrhythmias in patients undergoing congenital heart surgery
}

\author{
Doğumsal kalp cerrahisi yapılan hastalarda ameliyat sonrası erken dönem aritmiler
}

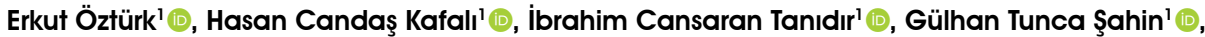

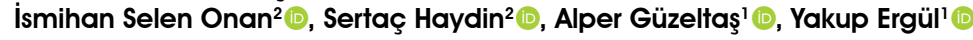

\author{
'Department of Pediatric Cardiology, University of Health Sciences, Istanbul Mehmet Akif Ersoy Thoracic and Cardiovascular Surgery \\ Training and Research Hospital, Istanbul, Turkey \\ ${ }^{2}$ Department of Pediatric Cardiovascular Surgery, University of Health Sciences, Istanbul Mehmet Akif Ersoy Thoracic and Cardiovascular Surgery \\ Training and Research Hospital, Istanbul, Turkey
}

\begin{abstract}
Background: This study aims to evaluate early postoperative arrhythmias in children undergoing congenital cardiac surgery.

Methods: A total of 670 pediatric patients (355 males, 315 females; median age: 4 months; range, 1 day to 18 years) who underwent cardiac surgery due to congenital heart defects between December 2018 and November 2019 were included. The rate of postoperative arrhythmias, diagnosis, potential risk factors, and management strategies were evaluated. Multivariate regression analysis was used to identify significant factors of development of postoperative arrhythmias.
\end{abstract}

Results: Tachyarrhythmia was detected in 54 patients (8.1\%), and the most common tachyarrhythmia was junctional ectopic tachycardia. Medical treatment was required in 25/38 (66\%) of junctional ectopic tachycardia patients. Amiodarone was initiated in 18 , dexmedetomidine in five, and flecainide + amiodarone in two of the patients. Different degrees of atrioventricular block were observed in 30 patients $(4.5 \%)$. In 12 patients, permanent pacemakers were implanted during hospitalization. Age at the time of surgery under one-year-old, high inotropic scores, prolonged operation time, and high Aristotele's scores were independent risk factors associated with early postoperative arrhythmia $(\mathrm{p}<0.05)$. The most common operations associated with early postoperative arrhythmia were left ventricular outflow tract, $(6 / 20,30 \%)$, complete atrioventricular septal defect $(13 / 53,24 \%)$, and tetralogy of Fallot (20/134, 14\%) surgeries.

Conclusion: Cardiac arrhythmias are common in the early period after congenital heart surgery in children. The diagnosis and frequency of arrhythmias may vary according to different surgical procedures.

Keywords: Arrhythmia, children, congenital heart surgery, intensive care.

\section{$\ddot{O} Z$}

Amaç: Bu çalışmada, doğumsal kalp cerrahisi yapılan çocuklarda ameliyat sonrası erken dönemdeki aritmiler değerlendirildi.

Çalışma planı: Aralık 2018-Kasım 2019 tarihleri arasında doğumsal kalp defektleri nedeniyle kalp cerrahisi yapılan toplam 670 pediatrik hasta (355 erkek, $315 \mathrm{k} 1 \mathrm{z}$; medyan yaş: 4 ay; dağılım, 1 gün ila 18 yıl) çalışmaya alındı. Ameliyat sonrası aritmilerin oranı, tanısı, muhtemel risk faktörleri ve tedavi stratejileri değerlendirildi. Ameliyat sonrası aritmi gelişiminin anlamlı faktörlerini tespit etmek için çok değişkenli regresyon analizi kullanıldı.

Bulgular: Elli dört hastada (\%8.1) taşiaritmi saptanmış olup, en sık gözlenen aritmi junctional ektopik taşikardi idi. Junctional ektopik taşikardi hastalarının 25/38'inde (\%66) medikal tedavi gerekti. Hastaların 18'ine amiodaron, beşine deksmedetomidin ve ikisine flekainid + amiodaron başland. Otuz hastada (\%4.5) değişik derecelerde atriyoventriküler blok gözlendi. On iki hastaya hastane yatışı sırasında kalıcı kalp pili takıldı. Ameliyat sırasında 1 yaş altı olmak, yüksek inotrop skoru, uzun ameliyat süresi ve yüksek Aristotole skorları ameliyat sonrası erken dönemde aritminin bağımsız risk faktörleri idi $(\mathrm{p}<0.05)$. Ameliyat sonrası erken dönemde aritmi ile en fazla ilişkili ameliyatlar sol ventrikül çıkım yolu (6/20, \%30), komplet atriyoventriküler septal defekt $(13 / 53, \% 24)$ ve Fallot tetralojisi ameliyatlar1 (20/134,\%14) idi.

Sonuç: Kardiyak aritmiler, çocuklarda doğumsal kalp cerrahi sonrası erken dönemde sık görülür. Farklı cerrahi işlemlere göre aritmi tanısı ve sıklı̆̆ değişebilmektedir.

Anahtar sözcïkler: Aritmi, çocuk, doğumsal kalp cerrahisi, yoğun bakım.

Received: July 03, 2020 Accepted: October 27, 2020 Published online: January 13, 2021

Correspondence: Erkut Öztürk, MD. SBÜ İstanbul Mehmet Akif Ersoy Göğüs Kalp ve Damar Cerrahisi Eğitim ve Araştırma Hastanesi, Çocuk Kardiyoloji Kliniği, 34303 Küçükçekmece, Istanbul, Türkiye.

Tel: +90 212 - 6922000 e-mail: erkut_ozturk@yahoo.com 
Arrhythmias are well-known complications after congenital heart disease operations. They are usually temporary in most cases and resolves with medical treatment. Despite this, they may affect mortality and morbidity in intensive care by causing significant hemodynamic deterioration..$^{[1,2]}$

The main causes of arrhythmias in the early postoperative period are direct injury to the cardiac conduction system during surgery or edema and inflammation in myocardial tissue in areas close to the conduction system. In addition, it has been suggested that different conditions such as ischemia and reperfusion injury associated with cardiopulmonary bypass (CPB), electrolyte imbalance, acidosis or alkalosis, age at the time of operation, hemodynamics, acidosis, pain, sedation, and inotropic drugs and doses may affect the development and frequency of arrhythmias. ${ }^{[3-5]}$

In particular, in pediatric patients, postoperative arrhythmias can be life-threatening. Urgent correct diagnosis and appropriate management should be provided for preventing further complications. Although arrhythmias commonly regress spontaneously or with medical treatment, additional interventional treatment such as defibrillation or permanent pacemaker implantation may be required in some cases. ${ }^{[6]}$

In the present study, we aimed to evaluate the incidence of arrhythmias and to analyze possible risk factors during early postoperative period in children who underwent congenital heart surgery. The treatment protocols for arrhythmias in these patients were also evaluated.

\section{PATIENTS AND METHODS}

This retrospective study was conducted at Istanbul Mehmet Akif Ersoy Thoracic and Cardiovascular Surgery Training and Research Hospital Department of Pediatric Cardiology between December $1^{\text {st }}$, 2018 and November $30^{\text {th }}$, 2019. The study center is a high-volume tertiary cardiac center. A total of 670 pediatric patients (355 males, 315 females; median age: 4 months; range, 1 day to 18 years) who underwent congenital heart surgery due to congenital heart defects were included. Those with preexisting or transient rhythm abnormalities in the operation theater which did not recur postoperatively were excluded. The preoperative demographic data including age, sex, and weight and anatomical diagnosis, surgical data, clinical follow-up, and postoperative intensive care unit (ICU) records of the patients were evaluated. A written informed consent was obtained from each parent. The study protocol was approved by the Istanbul Mehmet Akif Ersoy Thoracic and Cardiovascular Surgery Training and Research Hospital Ethics Committee (Approval Date/ No:2019/60). The study was conducted in accordance with the principles of the Declaration of Helsinki.

The telemetric recording system was utilized through the postoperative follow-up of the patients in the ICU. This recording system provided additional data by means of monitoring invasive arterial pressure, central venous pressure, pulse oximetry, core temperature and near-infrared spectroscopy.

All children were intensively monitored in the early postoperative period (Week 1) for the detection of any rhythm abnormality. The patients were considered arrhythmic, if arrhythmia persisted longer than $30 \mathrm{sec}$ or recurred and/or led to a hemodynamic instability. In case of multiple arrhythmias in the same patient, the initial arrhythmia was taken into consideration. To overcome diagnostic difficulties, further examinations were performed with 12-channel electrocardiography (ECG), Holter ECG, and atrial ECG \pm adenosine. Hemodynamically insignificant entities such as sinus tachycardia and atrial/ventricular ectopic rhythms were excluded from the analysis, given the fact that they are seen quite frequently in postoperative cases, mostly due to pain, sedation, or fever.

Arrhythmias which were initially examined by a single pediatric cardiac intensive care unit (PCICU) specialist was, then, confirmed by two different pediatric cardiologists and a pediatric electrophysiologist. Arrhythmias were grouped as junctional ectopic tachycardia (JET), supraventricular tachycardia (SVT), ventricular tachycardia (VT), ventricular fibrillation (VF), atrial fibrillation (AF) atrial flutter (AFL), and atrioventricular (AV) block (first, second, complete).

The diagnosis of JET was made based on the typical ECG appearance with narrow QRS complexes at a rate between 170 to $260 \mathrm{bpm}$ and $\mathrm{AV}$-dissociation where the atrial rate was slower than the ventricular rate. ${ }^{[7]}$ Supraventricular tachycardia was defined as $\mathrm{AV}$ reentrant (retrograde $\mathrm{P}$ waves) or with 1:1 AV conduction. $\mathrm{P}$ waves absent/abnormal, inverted $\mathrm{P}$ waves in II, III, aVF, a heart rate of $>220$ in infants and $>160 \mathrm{bpm}$ in children. Supraventricular tachycardia included ectopic atrial tachycardia, AV nodal reentrant tachycardia, and AV reentrant tachycardia. Atrial flutter was indicated by an atrial heart rate between 240 and $400 \mathrm{bpm}$ and AV node conduction block, characterized by a saw-tooth ECG pattern in leads II, III, and 
$\operatorname{aVF}^{[8]}$ Other arrhythmias were identified according to standard definitions. ${ }^{[2,4]}$ A minimal sinus rate of $120 \mathrm{bpm}$ in children younger than two years of age, and a sinus rate of $100 \mathrm{bpm}$ in children older than two years of age were defined as adequate.

For all patients, serum electrolytes (sodium, potassium, magnesium, and ionized calcium) and lactate were measured at every 4-h intervals from the time of PCICU admission. The mean values of the serum electrolyte levels measured within the first $72 \mathrm{~h}$ of the PCICU admission and the highest value of serum lactate levels measured during the first $72 \mathrm{~h}$ after the PCICU admission were included in the statistical analysis.

Inotropic support was initiated in patients with ventricular dysfunction and low cardiac output syndrome. Inotropic agent use was scored on a daily basis. The vasoactive-inotropic score (VIS) was calculated using the following formula: VIS=dopamine dose $(\mu \mathrm{g} / \mathrm{kg} / \mathrm{min})+$ dobutamine dose $(\mu \mathrm{g} / \mathrm{kg} / \mathrm{min})+100 \times$ epinephrine dose $(\mu \mathrm{g} / \mathrm{kg} / \mathrm{min})+10 \times$ milrinone dose $(\mu \mathrm{g} / \mathrm{kg} / \mathrm{min})$
$+10,000 \times$ vasopressin dose $(\mu \mathrm{g} / \mathrm{kg} / \mathrm{min})+100 \times$ norepinephrine dose $(\mu \mathrm{g} / \mathrm{kg} / \mathrm{min}){ }^{[9]}$

The Risk Adjustment for Congenital Heart Surgery-1 (RACHS-1), ${ }^{[10]}$ and Aristotle Comprehensive Complexity (ACC) score $^{[11]}$ were used to classify the procedures. The RACHS-1 system scale ranges from one to six. The ACC score level between one and four (Level 1 [1.5 to 5.9]; Level 2 [6.0 to 7.9]; Level 3 [8.0 to 9.9]; and Level 4 [10.0 to 15.0$])$.

In all patients with CPB or median sternotomy, atrial and ventricular temporary epicardial pacing wires were placed postoperatively. Treatment of the arrhythmias was decided by the management team on case-by-case basis. A simple algorithm was used, while approaching to the treatment.

The presence and diagnosis of arrhythmia was identified by 12 -lead ECG \pm atrial ECG, \pm adenosine administration. Advanced cardiac life support (ACLS) and defibrillation were administered in case of hemodynamic instability or arrhythmia requiring shock (particularly for VT or VF). High-dose

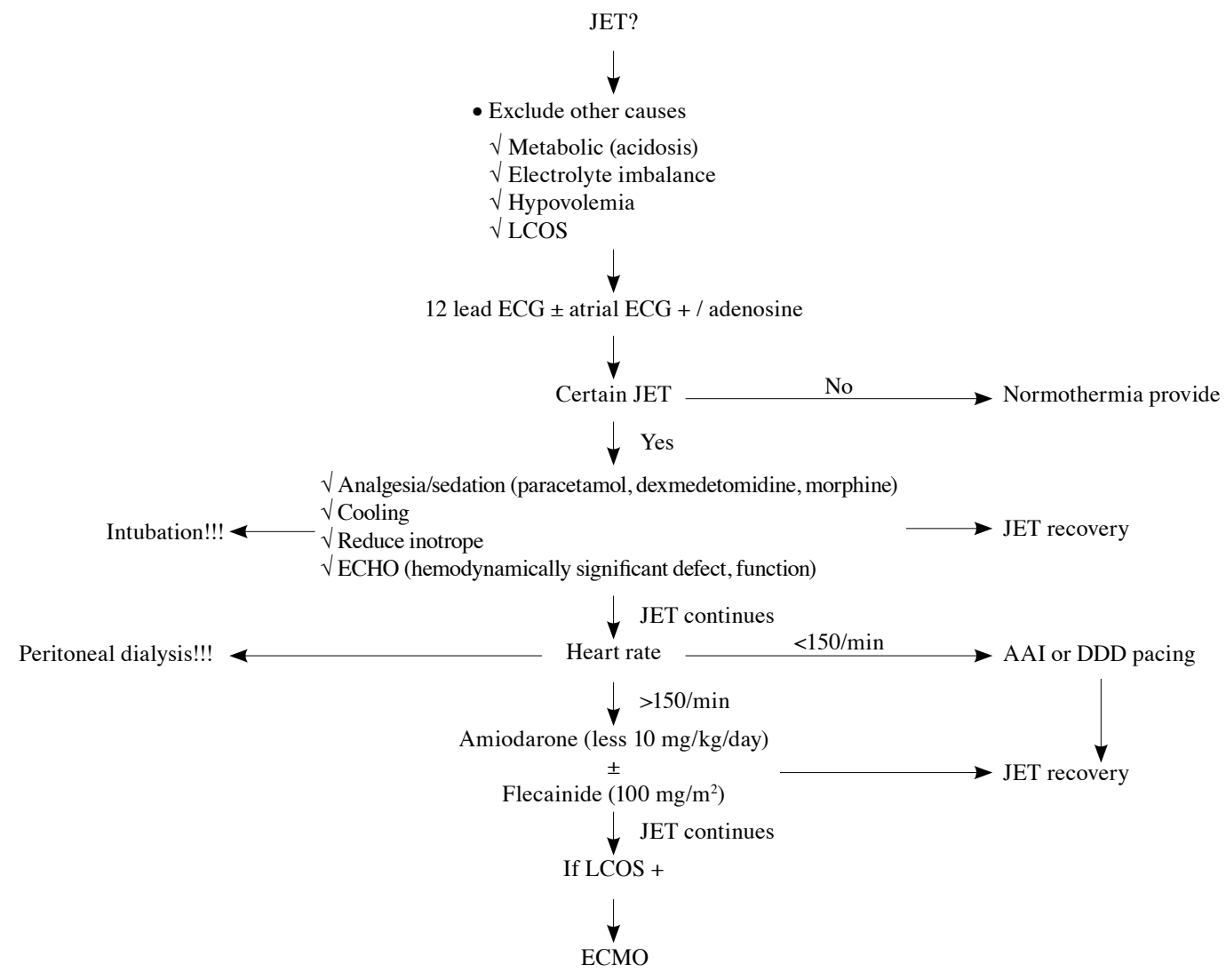

Figure 1. Algorithm for management of Junctional ectopic tachycardia.

JET: Junctional ectopic tachycardia; LCOS: Low cardiac output syndrome; ECG: Electrocardiography; ECHO: Echocardiography; ECMO: Extracorporeal membrane oxygenation. 
adenosine (200 $\mu \mathrm{g} / \mathrm{kg}$ intravenous [IV] bolus) and/or $1-2 \mathrm{~J} / \mathrm{kg}$ cardioversion (CV) was administered for SVT. In case of AFL, sinus rhythm was attempted to be restored by rapid atrial pacing and, if it failed, $\mathrm{CV}$ with 1-2 J/kg was applied. Transient pacing support was provided to increase cardiac output, in case of sinus bradycardia or complete AV block. Preload was primarily optimized. Maximal care was given to prevent electrolyte imbalance (calcium, potassium, magnesium and sodium). Optimal sedation (dexmedetomidine as the first option, fentanyl \pm midazolam as the second option), pain control (paracetamol) and core body temperature control were provided. Minimal or no use of inotropes was preferred to reduce chronotropy. Milrinone $(0.5 \mu \mathrm{g} / \mathrm{kg} / \mathrm{min})$, an inodilator, and/or norepinephrine $(0.05-0.1 \mu \mathrm{g} / \mathrm{kg} / \mathrm{min})$ were initiated to manage left ventricular/right ventricular dysfunction, if present. The presence of a residual defect and cardiac functions were evaluated by echocardiography at every stage of the process. Extracorporeal membrane oxygenation (ECMO) was considered in the presence of any sudden cardiac arrest. The JET algorithm is summarized in Figure 1.

\section{Statistical analysis}

Statistical analysis was performed using the SPSS for Windows version 15.0 software (SPSS Inc., Chicago, IL, USA). Continuous variables were expressed in median (min-max) values, while categorical variables were expressed in number and frequency. The Mann-Whitney $U$ test, chi-square test, or Fisher's exact test were used for statistical analysis, where applicable. The correlations between the scores and outcome were analyzed by Spearman's rho correlation coefficient. Univariate analysis was performed to identify predictors of arrhythmia. Significant variables were included in the multivariate logistic regression model, and odds ratio (OR) was calculated. A $p$ value of $<0.05$ was considered statistically significant.

\section{RESULTS}

Of the patients included in the study, the median weight was five (range, 2.5 to 70 ) $\mathrm{kg}$. A total of $91 \%$ of the operations were performed under CPB. The median ICU stay was three (range, 1 to 150) days. The RACHS-1 score was $\geq 4$ in $15.2 \%$ of the cases. Demographic and clinical characteristics of the patients are shown in Table 1.

The most common diagnosis was ventricular septal defect (VSD) $(\mathrm{n}=140)$ and tetralogy of Fallot (TOF) $(n=134)$. Eighty-four patients $(12.4 \%)$ had arrhythmia.
The most common arrhythmia was JET $(n=38,5.6 \%)$, followed by complete heart block (CHB) $(n=23 ; 3.4 \%)$, (SVT) $(n=8 ; 1.2 \%)$, and VT $(n=4 ; 0.6 \%)$. The rate of arrhythmias and surgical techniques are shown in Table 2 and Table 3, respectively.

In cases with the first- and second-degree AV block, the diagnosis was confirmed within the first $48 \mathrm{~h}$ postoperatively. None of them were hemodynamically significant. All of the four second-degree AV blocks resolved spontaneously. One of the first-degree AV blocks was improved, while the other two persisted.

Of the patients with complete AV block, 21 were diagnosed after the operation and two within the first $24 \mathrm{~h}$. They were all supported with a temporary pacemaker. Complete recovery was observed in 11 of these patients. Four patients had full recovery within the postoperative first three days, eight in the first seven days, and 10 in the first 10 days, respectively. On Day 5 postoperatively, JET developed in a patient and returned to the normal sinus rhythm on Day 12 . A permanent pacemaker was inserted in 12 patients, among those four underwent left ventricular outflow tract (LVOT) surgery, three had complete AV septal defect (AVSD) surgery, two had complete correction of TOF, two had intraventricular tunnel repair, and one had VSD closure.

Among 38 patients with a diagnosis of JET, 34 were detected within the postoperative first $24 \mathrm{~h}$, three within the first $48 \mathrm{~h}$, and one within the first $72 \mathrm{~h}$. For the treatment approach of these cases, traditional measures including reduction of inotrope perfusions, providing sedation and analgesia, temperature control and correction of electrolyte abnormalities were used in 13 patients. Junctional ectopic tachycardia was attempted to be controlled with amiodarone (10 to $15 \mathrm{mg} / \mathrm{kg} /$ day) in 18 cases, with dexmedetomidine $(0.5 \mu \mathrm{g} / \mathrm{kg} / \mathrm{h})$ in five cases, and with amiodarone + flecainide $\left(100 \mathrm{mg} / \mathrm{m}^{2}\right)$ in two cases. Reverse sequential pacing was not required in any of the patients. One patient necessitated ECMO support, since JET could not be controlled, despite proper antiarrhythmic therapy. Two patients with JET died due to low cardiac output syndrome. Recovery was achieved within the first eight postoperative days in all patients who recovered from JET. A permanent pacemaker was implanted in a patient who had complete AV block after JET.

Atrial fibrillation developed in one patient with total anomalous pulmonary venous return (TAPVR). Cardioversion was performed at $1 \mathrm{~J} / \mathrm{kg}$ providing normal sinus rhythm without a recurrence afterwards. 
Table 1. Demographic and clinical characteristics of patients

\begin{tabular}{lcccc}
\hline & $\mathrm{n}$ & $\%$ & Median & Range \\
\hline Age (<30 days) & 80 & 12 & & \\
Sex & & & & \\
$\quad$ Male & 355 & 53 & & \\
Median age (range) & & & 4 months & 1 day -18 years \\
Median weight (range) & & & $5 \mathrm{~kg}$ & $2.5-70 \mathrm{~kg}$ \\
Cardiopulmonary bypass & 610 & 91 & & \\
Operation time (min) & & & 85 & $0-255$ \\
Aortic clamp time (min) & & & 40 & $0-119$ \\
Intensive care & & & & 16 \\
$\quad$ Intubation time (h) & & & 3 & $1-480$ \\
$\quad$ Intensive care stay duration (days) & & & 5 & $0-50$ \\
$\quad$ Vasoactive inotropic score & & & & \\
RACHS-1 score & 568 & 84.8 & & \\
$\quad<4$ & 102 & 15.2 & & \\
$\quad \geq 4$ & & & & \\
Aristotle comprehensive complexity score & 67 & 10.0 & & \\
$\quad$ Level 1 (1.5-5.9) & 191 & 28.5 & \\
Level 2 (6.0-7.9) & 172 & 25.7 & \\
Level 3 (8.0-9.9) & 240 & 35.8 & & \\
Level 4 (10.0-15) & &
\end{tabular}

RACHS-1: Risk Adjustment for Congenital Heart Surgery.

Eight patients had SVT, four of them returned to normal sinus rhythm after adenosine (100 to $300 \mu \mathrm{g} / \mathrm{kg}$, IV bolus) application. Cardioversion was needed in one patient. Three patients required antiarrhythmic therapy, their diagnoses and therapy regimens were as follows: TAPVR (amiodarone + propranolol $(3 \mathrm{mg} / \mathrm{kg} / \mathrm{day})$ + flecainide), VSD (propranolol), and double outlet right ventricle (propranolol).
Patients who developed VF/VT $(n=7)$ were managed according to the current ALCS guidelines. ${ }^{[4]}$ The patients with VT/VF received either lidocaine IV bolus at a dose of 1 to $2 \mathrm{mg} / \mathrm{kg}$ or amiodarone IV bolus at a dose of $5 \mathrm{mg} / \mathrm{kg}$. Two patients with prior LVOT surgery and one patient who had previous mitral valve surgery were discharged from the hospital with the initiation of additional propranolol treatment. The management of the patients according

Table 2. Arrhythmia types and frequencies

\begin{tabular}{lccc}
\hline & & \multicolumn{2}{c}{ Incidence (\%) } \\
\cline { 3 - 4 } & $\mathrm{n}$ & Arrhythmia group $(\mathrm{n}=84)$ & Total $(\mathrm{n}=670)$ \\
\hline $1^{\text {st }}$ degree AV block & 3 & 3.5 & 0.4 \\
$2^{\text {nd }}$ degree AV block & 4 & 4.7 & 0.6 \\
Complete AV block & 23 & 27.3 & 3.4 \\
Junctional ectopic tachycardia & 38 & 45.2 & 5.6 \\
Supraventricular tachycardia & 8 & 9.5 & 1.2 \\
Atrial fibrillation & 1 & 1.2 & 0.1 \\
Ventricular tachycardia & 4 & 4.7 & 0.6 \\
Ventricular fibrillation & 3 & 3.9 & 0.4 \\
Total & 84 & 100 & 12.3 \\
\hline
\end{tabular}

AV: Atrioventricular. 
Table 3. Incidence of arrhythmia according to operation type

\begin{tabular}{|c|c|c|}
\hline & $\begin{array}{c}\text { Procedure } \\
\text { (n) }\end{array}$ & $\begin{array}{c}\text { Frequency } \\
(\%)\end{array}$ \\
\hline \multicolumn{3}{|l|}{ Complete AV block $(n=23)$} \\
\hline Others $*(n=40)$ & 4 & 10 \\
\hline TOF repair $(n=134)$ & 4 & 3 \\
\hline VSD closure $(n=140)$ & 3 & 2.1 \\
\hline AVSD repair $(n=53)$ & 4 & 7.5 \\
\hline LVOT surgery $(n=20)$ & 5 & 25 \\
\hline $\operatorname{ASO}(n=32)$ & 1 & 3.1 \\
\hline TAPVC/PAPVC $(\mathrm{n}=49)$ & 2 & 4 \\
\hline \multicolumn{3}{|l|}{$\operatorname{JET}(\mathrm{n}=38)$} \\
\hline Others $*(n=40)$ & 3 & 7.5 \\
\hline TOF repair $(n=134)$ & 14 & 10.4 \\
\hline VSD closure $(n=140)$ & 6 & 4.3 \\
\hline AVSD repair $(n=53)$ & 6 & 11.3 \\
\hline $\operatorname{ASO}(n=32)$ & 1 & 3.1 \\
\hline Glenn-Fontan procedure & 2 & 2.3 \\
\hline$(n=86)$ & 1 & 5.5 \\
\hline \multicolumn{3}{|l|}{ BT shunt $(\mathrm{n}=18)$} \\
\hline \multicolumn{3}{|l|}{ Atrial fibrillation $(\mathrm{n}=1)$} \\
\hline TAPVC/PAPVC $(\mathrm{n}=49)$ & 1 & 2 \\
\hline \multicolumn{3}{|l|}{$\operatorname{SVT}(n=8)$} \\
\hline Others* $(n=40)$ & 2 & 5 \\
\hline TOF repair $(n=134)$ & 2 & 1.5 \\
\hline VSD closure $(n=140)$ & 1 & 0.7 \\
\hline $\operatorname{AVSD}(n=53)$ & 1 & 1.8 \\
\hline $\operatorname{ASO}(n=32)$ & 1 & 3.1 \\
\hline TAPVC/PAPVC $(\mathrm{n}=49)$ & 1 & 2 \\
\hline \multicolumn{3}{|l|}{ VT and VF $(n=7)$} \\
\hline Others $*(n=40)$ & 1 & 2.5 \\
\hline AVSD repair $(n=53)$ & 2 & 3.8 \\
\hline $\operatorname{ASO}(n=32)$ & 1 & 3.1 \\
\hline LVOT surgery $(n=20)$ & 1 & 5 \\
\hline BT shunt $(n=18)$ & 1 & 5.5 \\
\hline Repair of ALCAPA $(n=7)$ & 1 & 14.2 \\
\hline
\end{tabular}

AV: Atrioventricular; TOF: Tetralogy of Fallot; VSD: Ventricular septal defect; AVSD: Atrioventricular septal defect; LVOT: Left ventricular outflow tract; ASO: Arterial switch operation; TAPVC/PAPVC: Total anomalous pulmonary venous connection/partial anomalous pulmonary venous connection; JET: Junctional ectopic tachycardia; BT: Blalock-Taussig; SVT: Supraventricular tachyarrhythmia; VT: Ventricular tachycardia; VF: Ventricular fibrillation; ALCAPA: Anomalous left coronary artery from the pulmonary artery; * Others include intraventricular tunnel repair, mitral valve repair, pulmonary valve replacement, cone operation, and tricuspid valve repair.

to their arrhythmia subgroups is summarized in Figure 2.

In univariate analysis, age of $<1$ year, higher RACHS-1 category, higher Aristotle's level, procedure requiring $\mathrm{CPB}$, higher $\mathrm{CPB}$, and higher VIS were
Table 4. Multiple regression analysis results

\begin{tabular}{lccc}
\hline Variable & Odds ratio & $95 \%$ CI & $p$ \\
\hline Age $<1$ year & 1.96 & $1.18-3.24$ & 0.009 \\
RACHS category $\geq 4$ & 2.21 & $1.72-4.04$ & 0.032 \\
Aristotle level $\geq 3$ & 2.32 & $1.18-4.81$ & 0.024 \\
CPB time $>140$ min & 1.87 & $0.89-3.95$ & 0.046 \\
VIS $24^{\text {th }} \mathrm{h}>10$ & 1.91 & $0.67-5.42$ & 0.030 \\
\hline CI: Confidence interval; RACHS-1: Risk Adjustment for Congenital Heart \\
Surgery; CPB: Cardiopulmonary bypass; VIS: Vasoactive-inotropic score.
\end{tabular}

found to be significantly associated with postoperative arrhythmia $(\mathrm{p}<0.05)$. In the multivariate analysis, a cut-off value for $\mathrm{CPB}$ time was calculated as 140 min, whereas a VIS of $>10$ indicated high inotropic requirement. When independent risk factors affecting arrhythmia development were evaluated, the multivariate analysis revealed that age of $<1$ year, a RACHS- 1 category $\geq 4$, an Aristotle's level of $\geq 3$, a CPB time of $>140 \mathrm{~min}$, and a VIS of $>10$ at $24 \mathrm{~h}$ were found to be independent risk factors (Table 4).

\section{DISCUSSION}

In this study, the frequency of early postoperative arrhythmia in children who had congenital cardiac surgery in a high-volume tertiary cardiac center and the factors affecting were investigated. The most common arrhythmia was JET, whereas LVOT, TOF, and complete AVSD surgeries were the most common operations associated with the development of arrhythmias. We found that age $<1$ year, the level of surgical complexity (RACHS- 1 category $\geq 4$, Aristotle's level $\geq 3$ ), high VIS scores, and prolonged CPB time were the major independent risk factors for the development of arrhythmia.

Despite the improvement of perfusion techniques, innovations in operative techniques, and advances in intensive care management, arrhythmias still continue to be one of the important causes of mortality and morbidity in the postoperative period. Different rates have been reported in the literature regarding the frequency of arrhythmia in the early postoperative period. The prevalence of postoperative arrhythmias was reported as $14.4 \%, 27 \%$, and $48 \%$ in the studies of Jain et al., ${ }^{[6]}$ Pfammatter et al. ${ }^{[3]}$ and Valsangiacomo et al., ${ }^{[12]}$ respectively. Differences in diagnostic methods, inclusion of sinus tachycardia, supraventricular ectopic beats, and ventricular extrasystoles as arrhythmias may contribute to the discrepancy in the reported prevalence. In our study, the prevalence of arrhythmia was found to be $8.1 \%$. Compared to other studies, 


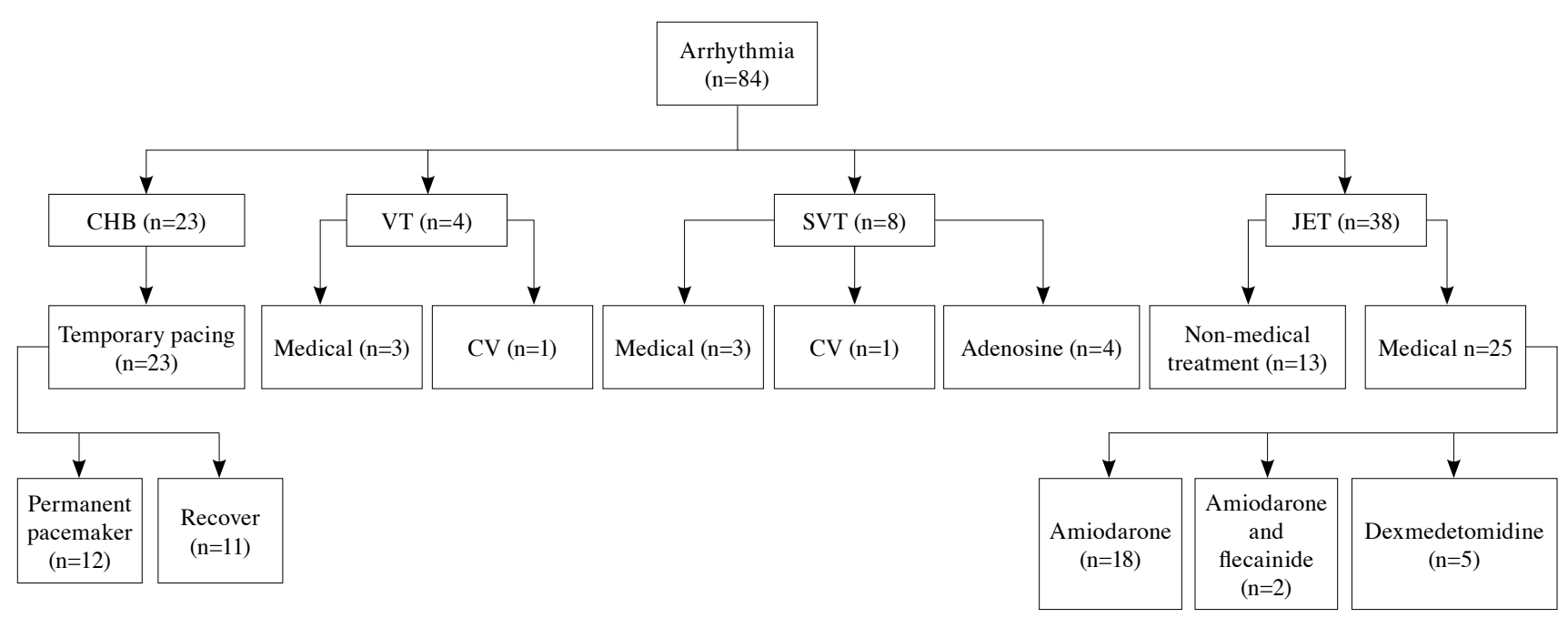

Figure 2. Therapeutic approach to rhythm abnormalities.

CHB: Complete heart block; VT: Ventricular tachycardia; SVT: Supraventricular tachycardia; JET: Junctional ectopic tachycardia; CV: Cardioversion.

inclusion of arrhythmias only if it lasts longer than $30 \mathrm{sec}$, excluding ectopic beats and, as being one of the most recent studies, taking advantage of up-to-date myocardial protection and surgical techniques may have had effects on the lower rates in our study.

The rate of arrhythmia development can show variation for each surgical procedure. In the study of Jain et al., ${ }^{[6]}$ the complete AV block rate was the highest after AVSD, TOF, and Fontan surgery. On the other hand, the rate of JET was the highest after AVSD operation, intraventricular tunnel, and TOF surgeries. In another study, Sahu et al ${ }^{[13]}$ reported that the most frequent postoperative arrhythmia was JET and it was most commonly seen after AVSD and TOF operations. Alp et al. ${ }^{[14]}$ also reported that different types of arrhythmias were seen in $41 \%$ of patients after VSD operation, in $25 \%$ of patients after atrial septal defect closure, in $11.4 \%$ of patients after TOF operation, and in $9.5 \%$ of AVSD cases. In our study, the complete AV block rate after LVOT surgery and JET rate after TOF and AVSD surgeries were found to be significantly higher.

Junctional ectopic tachycardia is commonly seen after congenital heart surgery. In children, JET may be seen within the first $72 \mathrm{~h}$ after cardiac surgery. It is usually caused by a direct trauma, and ischemic or stretch injury to the $\mathrm{AV}$ conduction tissues during surgical repair of congenital heart defects. Its incidence varies between 1 and $15 \%$ in the literature. ${ }^{[15-17]}$ It has been suggested that being younger than six months old, prolonged CPB and aortic cross- clamp time, myocardial ischemia/injury, postoperative use of dopamine or milrinone, acidosis, electrolyte disturbance (hypomagnesemia, hypokalemia or hypocalcemia), and hypovolemia may be possible risk factors. ${ }^{[15-17]}$ The type of cardiac surgery is also another factor, particularly those involving the crux of the heart including TOF, AV canal, and VSD repair. However, JET was also reported after operations such as arterial switch and aortic arch surgeries in which the operation sites were far from the AV node. ${ }^{[15-17]}$

In the series of Moak et al. ${ }^{[18]}$ including 750 cases, JET was found in $19.5 \%$ of single-ventricle patients and $19.3 \%$ of patients with conotruncal defects postoperatively. In the study of Paluszek et al. ${ }^{[19]}$ including only TOF patients, the rate of JET was $13.3 \%$. In the series of Talwar et al., ${ }^{[2]} 46.6 \%$ of the postoperative arrhythmias were caused by JET. Similar to the current studies, the rate of JET was $5.6 \%$, accounting for $45.2 \%$ of all early postoperative arrhy thmias in our study.

Different diagnostic methods such as surface ECG, atrial ECG, and adenosine administration during atrial ECG may be needed for the diagnosis of JET. Dissociated $P$ waves can be seen on surface ECG, if the JET rate is low. Atrial ECG is very useful, if the JET rate is high and $\mathrm{P}$ waves cannot be detected on surface ECG. Adenosine reveals dissociated P waves by creating a transient retrograde ventriculoatrial (VA) block and VA dissociation. This method is reported to be very useful in differentiating JET cases with 1:1 retrograde VA conduction from other 
tachyarrhythmia. ${ }^{[20,21]}$ Junctional ectopic tachycardia is a tachyarrhythmia that is usually self-limiting within a week; however, it may cause a decrease in cardiac output due to the high heart rate and loss of $\mathrm{AV}$ synchrony. The first measure in the treatment of JET is standard general precautions such as fever and pain control, sedation, and decreasing inotropes. In addition, different recommendations such as single or combined use of antiarrhythmic agents such as amiodarone, flecainide, landiolol, and procainamide, as well as temporary pacemaker insertion, have been reported in the literature. ${ }^{[20-22]}$ Recently, case series about ivabradine use have been described. ${ }^{[20]}$ It has been suggested that the application of these recommendations in the context of a protocol may be very useful. ${ }^{[17,20,21]}$ In our center, JET cases are effectively managed per protocol (Figure 1). We believe that atrial ECG is very helpful in diagnosis. The basic components of the management and treatment are as follows: excluding the residual hemodynamic defects, general measures (pain, sedation, mild cooling), electrolyte imbalance and correction of acidosis (early peritoneal dialysis), appropriate selection (first milrinone), and reduction of inotropes, antiarrhythmic treatment (amiodarone and/or dexmedetomidine) and ECMO support, when necessary. In our study, 34\% of JET patients returned to sinus rhythm with general precautions. However, amiodarone and dexmedetomidine were required in $52 \%$ and $13 \%$ of the patients, respectively.

Atrioventricular block is common after operations involving surgical regions close to the conducting system and occurs more frequently in direct procedures. Complete AV block is a hemodynamically important sequela and its incidence decreases to 1 to $5 \%$ from $25 \%$ with the development of modern surgical techniques and a better understanding of the anatomy of the conducting system. ${ }^{[22-24]}$ In a study, Murray et al., ${ }^{[25]}$ reported the incidence of complete AV block as $3.7 \%$, Ayyildiz et al. ${ }^{[26]}$ reported as $6.7 \%$.

Post-surgical complete AV block may be temporary or permanent. Although temporary AV block usually returns to sinus rhythm within the first seven to 10 days after surgery, there are cases with a prolonged recovery time, even months later. Weindling et al. ${ }^{[23]}$ reported that $63 \%$ of patients with AV block recovered in the postoperative first month and $97 \%$ of patients recovered within the first nine days after surgery. Jain et al.$^{[6]}$ reported that $71.4 \%$ of complete AV block resolved within 10 days and the remaining patients required pacemaker implantation. In our study, this rate was $4.4 \%$ for all degrees of $\mathrm{AV}$ blocks and $3.4 \%$ for complete AV block. The AV block was resolved in
$48 \%$ of cases. A permanent pacemaker was implanted between postoperative Days 7 to 10 to all of the cases, except for a patient who had complete AV block after the development of a late JET (postoperative Day 12).

Previous studies have suggested various risk factors for postoperative arrhythmia development such as younger age, electrolyte imbalance, prolonged CPB time, deep hypothermic circulatory arrest, surgery type, inotropic use, and cyanotic congenital heart disease. ${ }^{[5-6,13,27]}$ These factors have been proposed to provoke the release of free radicals and ischemiareperfusion injury ending with myocardial damage. ${ }^{[22,24]}$ In a study including 369 patients, Sahu et al. ${ }^{[13]}$ reported that higher Aristotle's level, prolonged operation time, hypotension, tachycardia, high inotropic scores, and high serum lactate levels were associated with the occurrence of postoperative arrhythmias. In the study of Jain et al. ${ }^{[6]}$ including 536 patients, age $<1$ year, RACHS-1 category $\geq 3$, and a cross-clamp time of $>67$ min were independent risk factors in the development of arrhythmia. In the study of Rekawek et al., ${ }^{[5]}$ younger age, lower body weight, higher Aristotle's basic score, longer $\mathrm{CPB} /$ aortic cross-clamp time, and use of deep hypothermia and circulatory arrest were reported as the risk factors for postoperative arrhythmias. Consistent with the literature, in our study, younger age ( $<1$ year), higher RACHS-1 category, and longer CPB time were found to be significant risk factors for development of arrhythmia.

The main limitation of this study is its singlecenter design which reflects our clinical experience in a limited number of patients. In addition, excluding minor arrhythmias might have affected the results. Also, we were unable to investigate the effect of arrhythmias on mortality and morbidity. Finally, the relationship between the cardiac biomarkers and arrhythmia incidence was unable to be examined. Further large-scale, long-term, prospective studies are needed to draw a firm conclusion on this subject.

In conclusion, cardiac arrhythmias are common problems in the early postoperative period after congenital heart surgery in children. The diagnosis and frequency of arrhythmia may vary according to surgical procedures. In the postoperative period, junctional ectopic tachycardia and atrioventricular blocks are the most common types of arrhythmias. Besides standard protocols, the management and treatment of patients with postoperative arrhythmias should be individualized.

\section{Declaration of conflicting interests}

The authors declared no conflicts of interest with respect to the authorship and/or publication of this article. 


\section{Funding}

The authors received no financial support for the research and/or authorship of this article.

\section{REFERENCES}

1. Kabbani MS, Al Taweel H, Kabbani N, Al Ghamdi S. Critical arrhythmia in postoperative cardiac children: Recognition and management. Avicenna J Med 2017;7:88-95.

2. Talwar S, Patel K, Juneja R, Choudhary SK, Airan B. Early postoperative arrhythmias after pediatric cardiac surgery. Asian Cardiovasc Thorac Ann 2015;23:795-801.

3. Pfammatter JP, Bachmann DC, Wagner BP, Pavlovic M, Berdat P, Carrel T, et al. Early postoperative arrhythmias after open-heart procedures in children with congenital heart disease. Pediatr Crit Care Med 2001;2:217-22.

4. Garson AJ. Diagnostic electrocardiology. In: Anderson RH, Baker E, Macartney F, Rigby M, Shinebourne E, Tynan M, editors. Paediatric cardiology. 2nd ed. Edinburgh: Churchill Livingstone; 2002. p. 295-378.

5. Rekawek J, Kansy A, Miszczak-Knecht M, Manowska M, Bieganowska K, Brzezinska-Paszke M, et al. Risk factors for cardiac arrhythmias in children with congenital heart disease after surgical intervention in the early postoperative period. $\mathbf{J}$ Thorac Cardiovasc Surg 2007;133:900-4.

6. Jain A, Alam S, Viralam SK, Sharique T, Kapoor S. Incidence, risk factors, and outcome of cardiac arrhythmia postcardiac surgery in children. Heart Views 2019;20:47-52.

7. Hoffman TM, Bush DM, Wernovsky G, Cohen MI, Wieand TS, Gaynor JW, et al. Postoperative junctional ectopic tachycardia in children: incidence, risk factors, and treatment. Ann Thorac Surg 2002;74:1607-11.

8. Tunca Sahin G, Ozturk E, Kasar T, Guzeltas A, Ergul Y. Sustained tachyarrhythmia in children younger than 1 year of age: Six year single-center experience. Pediatr Int 2018;60:115-21.

9. Wernovsky G, Wypij D, Jonas RA, Mayer JE Jr, Hanley FL, Hickey PR, et al. Postoperative course and hemodynamic profile after the arterial switch operation in neonates and infants. A comparison of lowflow cardiopulmonary bypass and circulatory arrest. Circulation 1995;92:2226-35.

10. Jenkins KJ, Gauvreau K, Newburger JW, Spray TL, Moller JH, Iezzoni LI. Consensus-based method for risk adjustment for surgery for congenital heart disease. J Thorac Cardiovasc Surg 2002;123:110-8.

11. Lacour-Gayet F, Clarke D, Jacobs J, Comas J, Daebritz S, Daenen W, et al. The Aristotle score: a complexity-adjusted method to evaluate surgical results. Eur J Cardiothorac Surg 2004;25:911-24.

12. Valsangiacomo E, Schmid ER, Schüpbach RW, Schmidlin D, Molinari L, Waldvogel K, et al. Early postoperative arrhythmias after cardiac operation in children. Ann Thorac Surg 2002;74:792-6.
13. Sahu MK, Das A, Siddharth B, Talwar S, Singh SP, Abraham A, et al. Arrhythmias in children in early postoperative period after cardiac surgery. World J Pediatr Congenit Heart Surg 2018;9:38-46.

14. Alp H, Narin C, Baysal T, Sarigül A. Prevalence of and risk factors for early postoperative arrhythmia in children after cardiac surgery. Pediatr Int 2014;56:19-23.

15. Makhoul M, Oster M, Fischbach P, Das S, Deshpande S. Junctional ectopic tachycardia after congenital heart surgery in the current surgical era. Pediatr Cardiol 2013;34:370-4.

16. Cools E, Missant C. Junctional ectopic tachycardia after congenital heart surgery. Acta Anaesthesiol Belg 2014;65:1-8.

17. Kylat RI, Samson RA. Junctional ectopic tachycardia in infants and children. J Arrhythm 2019;36:59-66.

18. Moak JP, Arias P, Kaltman JR, Cheng Y, McCarter R, Hanumanthaiah $S$, et al. Postoperative junctional ectopic tachycardia: risk factors for occurrence in the modern surgical era. Pacing Clin Electrophysiol 2013;36:1156-68.

19. Paluszek C, Brenner P, Pichlmaier M, Haas NA, Dalla-Pozza $\mathrm{R}$, Hagl C, et al. Risk factors and outcome of post fallot repair junctional ectopic tachycardia (JET). World J Pediatr Congenit Heart Surg 2019;10:50-7.

20. Krishna MR, Kunde MF, Kumar RK, Balaji S. Ivabradine in post-operative junctional ectopic tachycardia (JET): Breaking new ground. Pediatr Cardiol 2019;40:1284-8.

21. Entenmann A, Michel M, Herberg U, Haas N, Kumpf M, Gass $\mathrm{M}$, et al. Management of postoperative junctional ectopic tachycardia in pediatric patients: a survey of 30 centers in Germany, Austria, and Switzerland. Eur J Pediatr 2017;176:1217-26.

22. Choi HJ, Kim YH, Cho JY, Hyun MC, Lee SB, Kim KT. Early postoperative arrhythmias after open heart surgery of pediatric congenital heart diseas. Korean Journal of Pediatrics 2010;53:532-7.

23. Weindling SN, Saul JP, Gamble WJ, Mayer JE, Wessel D, Walsh EP. Duration of complete atrioventricular block after congenital heart disease surgery. Am J Cardiol 1998;82:525-7.

24. Seghaye MC. The clinical implications of the systemic inflammatory reaction related to cardiac operations in children. Cardiol Young 2003;13:228-39.

25. Murray LE, Smith AH, Flack EC, Crum K, Owen J, Kannankeril PJ. Genotypic and phenotypic predictors of complete heart block and recovery of conduction after surgical repair of congenital heart disease. Heart Rhythm 2017;14:402-9.

26. Ayyildiz P, Kasar T, Ozturk E, Ozyilmaz I, Tanidir IC, Guzeltas A, et al. Evaluation of permanent or transient complete heart block after open heart surgery for congenital heart disease. Pacing Clin Electrophysiol 2016;39:160-5.

27. Yildirim SV, Tokel K, Saygili B, Varan B. The incidence and risk factors of arrhythmias in the early period after cardiac surgery in pediatric patients. Turk J Pediatr 2008;50:549-53. 